\title{
House $x$ sex interaction effects on body weight and linear measurements of Coturnix quails
}

\section{Simeon Olutoye Olawumi}

Animal Breeding and Genetics Unit, Department of Animal Production and Health Sciences, Ekiti State University, Ado-Ekiti, Nigeria

\section{Email address:}

simeon.olawumi@eksu.edu.ng

\section{To cite this article:}

Simeon Olutoye Olawumi. House X Sex Interaction Effects on Body Weight and Linear Measurements of Coturnix Quails. Animal and Veterinary Sciences. Vol. 3, No. 1, 2015, pp. 18-21. doi: 10.11648/j.avs.20150301.14

\begin{abstract}
A total number of two hundred day-old quails of mixed sexes were assessed for body weight, wing length, thigh length and breast girth from third week to the tenth week of age. Analyzed data showed that there was highly significant $(\mathrm{P}<0.01)$ house $\mathrm{x}$ sex interaction effects on live body weight. This means that body weight is house and sex dependent. Male and female birds reared inside the cage were superior in terms of body weight to those on deep litter. Generally, the rate of growth from third to seventh week was higher across both housing systems and sexes, but decreased after seventh week of age. In the same vein, There was highly significant $(\mathrm{P}<0.01)$ house $\mathrm{x}$ sex interaction effects on wing length, thigh length and breast girth of quail birds. It infers that these growth traits are house and sex dependent. Male and female birds reared inside the cage were superior in terms of body weight and other growth traits to those on deep litter. Since cage birds were restricted, they were able to utilize feeds given optimally leading to increase in muscle cells and body size. In essence, cage system of rearing produced more quail meat than deep litter, and should be considered for increased productivity and animal proteins supply.
\end{abstract}

Keywords: Coturnix Quail, Sex, Deep Litter, Restriction, House

\section{Introduction}

Protein consumption per caput in developing countries was far below the recommended level of $67 \mathrm{~g}$ per day out of which $58 \%$ should be of animal sources [1]. In Nigeria, $5.5 \mathrm{~g}$ of animal protein per caput per day was reported instead of $38.9 \mathrm{~g}$ which was the recommended protein intake [1]. Adverse effects of low protein intake include malnutrition, kwashiorkor, stunted growth rate, infant mortality and low productivity in adult working class. For increased and sustained animal protein supply, rearing of poultry birds of all species cannot be downplayed. And the specie with fastest growth rate which can produce meat and eggs for human consumption within a short time is Coturnix quails. There is no taboo against its production and consumption in any community, has short gestation and generation interval, hardy and disease resistant. The meat is tender and highly nutritive with amazing taste, gamy flavor, low caloric value and high dry matter [2]. In addition, the meat is rich in proteins, vitamins, essential amino acids, saturated fatty acids and phospholipids [3]. Previous studies had observed significant sex effect on live weight of broilers [4], of quails [5] and carcass traits $[4,6,7,8]$ in broilers. While separate effect of sex on live weight of poultry species had been widely reported in literature, the interaction of sex with other vital factors affecting birds' productivity is rare in the literature. This refers to the combined effect or interfaces between the two factors vis-à-vis the performance of birds. In an earlier study, some researchers observed significant strain $\mathrm{x}$ sex interactions on live weight [9]. Furthermore, significant genotype $\mathrm{x}$ sex interaction effect on live weight and body linear measurements in broiler breeds were reported in another work [10]. In addition, significant $\operatorname{sex} x \operatorname{diet}$ interactions on carcass fat and boneless carcass (meat) were documented by some authors [4].

The present investigation was aimed at finding the housing and sex interaction effects on live weight and linear measurements of Coturnix quails. House $\mathrm{x}$ sex interaction effects refers to the ranking order of the birds' performance based on joint effects of the two important factors. Specifically, the study will reveal among other things:

a. housing system with superior growth rate

b. sex with significant growth rate under the available housing environment 


\section{Materials and Methods}

\subsection{Study Location}

The study was carried out at the Animal Breeding Unit, Teaching and Research Farm, Ekiti State University, AdoEkiti, between August, 2013 and November, 2013. Ado-Ekiti is situated along latitude $7^{0} 31^{1}$ and $7^{0} 49^{1}$ North of the Equator and longitude $5^{0} 71^{1}$ and $5^{0} 27^{1}$ East of the Greenwich Meridian. The city falls under Derived Savannah zone. The city enjoys two separate seasonal periods namely, Rainy (May-October) and Dry (November-April) seasons.

\subsection{Management and Experimental Birds}

A total number of 200 day-old quails of mixed sexes were sourced from local hatcheries and used for this study. The chicks were brooded using coal pot to supply heat for the first three weeks of life. Antibiotics and vitamins were administered as and when due. Their beddings are made up of dry wood shavings to prevent coccidiosis outbreak and high level of hygiene was maintained throughout the experimental period to ensure unhindered conducive environment for growth and to lower death rate.

At exactly three weeks old, the chicks were separated into sexes and into two housing systems, that is, cage and deep litter. The sex was determined correctly by plumage colouration at 21 days of age. Males were identified by those having rusty brown throat and breast feathers, and cloaca gland, a bulbous structure on the upper edge of the vent that secretes a white, foamy material. Females on the other hand were identified by those having light tan feathers with black speckling on the throat and upper breast. The birds were raised under same nutritional status and uniform management and environmental conditions. They were of the same age and were given chicks mash from $1^{\text {st }}$ day- $6^{\text {th }}$ week containing $21 \% \mathrm{CP}$ and $3000 \mathrm{Kcal} / \mathrm{kg} \mathrm{ME}$. Thereafter, they were switched over to layers mash containing $16 \% \mathrm{CP}$ and 2600 $\mathrm{Kcal} / \mathrm{kg}$ ME to the end of the $10^{\text {th }}$ week when the study was terminated.

\subsection{Data Collection}

The birds were weighed at week three (3) at the time they were separated into sexes and housing systems and subsequently at one week interval up to 10 weeks of age. Thirty (30) birds per sex and housing were taken at random for weighing after being starved overnight from the pens each time the exercise was carried out. Other linear measurements taken were wing length, thigh length and breast girth. Live body weights were weighed using sensitive top loading scale (gm), while other parts were measured with tailors tape rule in centimeter.

\subsection{Statistical Analysis}

Data collected were subjected to analysis of variance and the differences between means for sex and housing were separated using Duncan New Multiple Range Test [11].

The appropriate statistical model used is:

$$
\mathrm{Y}_{\mathrm{ijk}}=\mu+\mathrm{S}_{\mathrm{j}}+\mathrm{H}_{\mathrm{i}}+(\mathrm{SH})_{\mathrm{ij}}+\varepsilon_{\mathrm{ijk}}
$$

$\mathrm{Y}_{\mathrm{ijk}}=$ observation of the $\mathrm{k}^{\text {th }}$ population, of the $\mathrm{j}^{\text {th }}$ sex and $\mathrm{i}^{\text {th }}$ house

$\mu=$ common mean

$S_{j}=$ fixed effect of $j^{\text {th }}$ sex $(j=2)$

$\mathrm{H}_{\mathrm{i}}=$ fixed effect of $\mathrm{i}^{\text {th }}$ house $(\mathrm{i}=2)$

$(\mathrm{SH})_{\mathrm{ij}=}=$ fixed sex $\mathrm{x}$ house interaction effects

$\varepsilon_{\mathrm{ijk}}=$ random error

\section{Results and Discussion}

Table 1 showed the least square means for house $\mathrm{x}$ sex interaction effects on growth traits of coturnix quail. There was highly significant $(\mathrm{P}<0.01)$ house $\mathrm{x}$ sex interaction effects on live body weight. This means that body weight is house and sex dependent. Male and female birds reared inside the cage were superior in terms of body weight to those on deep litter. Since cage birds were restricted, they were able to utilize feeds given maximally leading to increase in muscle cells and body size. In essence, cage system of rearing produced more quail meat than deep litter, and should be considered for increased animal proteins supply. Generally, the rate of growth from $3^{\text {rd }}-7^{\text {th }}$ week was higher across both housing systems and sexes, but decreased after $7^{\text {th }}$ week of age. This implies that quails reach mature market weight faster and earlier than any other poultry species, and are therefore, capable of supplying high quality animal proteins needed to ameliorate the symptoms of malnutrition being witnessed in developing countries. The present finding was comparable to the observation of previous authors who found significant genotype $\mathrm{x}$ sex interaction effects on body weight in chickens [10].

Table 1 also represented house $\mathrm{x}$ sex interaction effects on wing length. There was highly significant $(\mathrm{P}<0.01)$ house $\mathrm{x}$ sex interaction effects on wing length of quail birds. Similar to the results obtained for body weight, wing length was house and sex dependent. Male and female birds reared inside the cage were superior in terms of wing length to those on deep litter. The reason that can be adduced for this is that since cage birds were restricted, the feeds given were utilized maximally not only for body size but also for increase in wing length above those on the floor inside the cage.

In the present study (Table 2), there was significant $(\mathrm{P}<0.01)$ house $\mathrm{x}$ sex interaction effects on thigh length of quail birds. With respect to this trait, floor birds recorded superior mean values in thigh length than those reared inside the cage. This also implies that this linear trait is house and sex dependent. This may be due to free movement and flight tendencies applicable to those on deep litter, whereas, those inside the cage were restricted and unable to exercise themselves as they would have loved to do. The present finding was in agreement with the observation of researchers who found significant genotype $\mathrm{x}$ sex interaction effects on shank length in chickens [10].

With regard to breast girth, house and sex also jointly influenced the length of this linear measurement (Table 2). Similar to results obtained for thigh length, deep litter quail 
birds had superior mean values than cage birds. Both males and females reared on deep litter recorded higher and significant $(\mathrm{P}<0.01)$ mean values than their mates inside the cage. This might be due to free movement and frequent flight allowable in the former housing system. The present finding was also comparable to the observation of some workers who found significant genotype $\mathrm{x}$ sex interaction effects on body girth in chickens [10].

\section{Conclusions}

It can be concluded from the results of present study that both the body weight and other linear body measurements are house and sex dependent. This implies that neither housing system nor sex affected the growth traits separately, but, their combined actions did. Birds reared inside cage were superior in terms of body weight and wing length, while reverse was the case for thigh length and breast girth.

Table 1. Least square means showing house x sex interaction effects on body weight and wing length of Coturnix quails.

\begin{tabular}{|c|c|c|c|c|c|c|}
\hline \multirow{2}{*}{ Traits } & \multirow{2}{*}{ Age (weeks) } & \multicolumn{2}{|c|}{ Cage } & \multicolumn{2}{|c|}{ Floor } & \multirow{2}{*}{ SE } \\
\hline & & M & $\mathbf{F}$ & M & $\mathbf{F}$ & \\
\hline \multirow{7}{*}{$\begin{array}{l}\text { Body weight } \\
\text { (g) }\end{array}$} & 3 & $71.80^{\mathrm{a}}$ & $68.60^{\mathrm{a}}$ & $56.10^{\mathrm{b}}$ & $54.37^{\mathrm{b}}$ & 2.11 \\
\hline & 4 & $96.77^{\mathrm{a}}$ & $95.27^{\mathrm{a}}$ & $78.63^{b}$ & $78.03^{\mathrm{b}}$ & 2.27 \\
\hline & 5 & $118.03^{\mathrm{a}}$ & $115.67^{\mathrm{a}}$ & $90.57^{\mathrm{b}}$ & $90.47^{\mathrm{b}}$ & 1.96 \\
\hline & 6 & $124.37^{b}$ & $140.73^{\mathrm{a}}$ & $107.87^{\mathrm{c}}$ & $104.93^{\mathrm{c}}$ & 2.73 \\
\hline & 7 & $129.73^{b}$ & $150.83^{\mathrm{a}}$ & $118.80^{\mathrm{c}}$ & $130.40^{\mathrm{b}}$ & 2.36 \\
\hline & 9 & $127.87^{\mathrm{c}}$ & $148.43^{b}$ & $120.20^{\mathrm{d}}$ & $163.27^{\mathrm{a}}$ & 2.09 \\
\hline & 10 & $134.50^{c}$ & $153.47^{b}$ & $125.17^{d}$ & $164.20^{\mathrm{a}}$ & 2.00 \\
\hline \multirow{8}{*}{ Wing Length (cm) } & 3 & $7.82^{\mathrm{ab}}$ & $8.00^{\mathrm{a}}$ & $7.53^{\mathrm{bc}}$ & $7.43^{\mathrm{c}}$ & 0.13 \\
\hline & 4 & $8.83^{\mathrm{ab}}$ & $8.42^{\mathrm{c}}$ & $8.62^{\mathrm{bc}}$ & $9.15^{\mathrm{a}}$ & 0.13 \\
\hline & 5 & 9.33 & 9.40 & 9.18 & 9.25 & 0.10 \\
\hline & 6 & $9.78^{\mathrm{a}}$ & $10.05^{\mathrm{a}}$ & $9.20^{\mathrm{b}}$ & $9.35^{b}$ & 0.12 \\
\hline & 7 & 9.62 & 9.38 & 9.50 & 9.58 & 0.09 \\
\hline & 8 & 9.70 & 9.72 & 9.70 & 9.67 & 0.08 \\
\hline & 9 & $9.80^{\mathrm{bc}}$ & $9.98^{\mathrm{ab}}$ & $9.68^{\mathrm{c}}$ & $10.20^{\mathrm{a}}$ & 0.10 \\
\hline & 10 & $9.80^{\mathrm{c}}$ & $10.20^{\mathrm{b}}$ & $9.55^{\mathrm{d}}$ & $10.60^{\mathrm{a}}$ & 0.08 \\
\hline
\end{tabular}

abcd: means with different superscripts along rows are significantly different $(\mathrm{P}<0.01)$

Table 2. Least square means showing house x sex interaction effects on thigh length and breast girth of Coturnix quails.

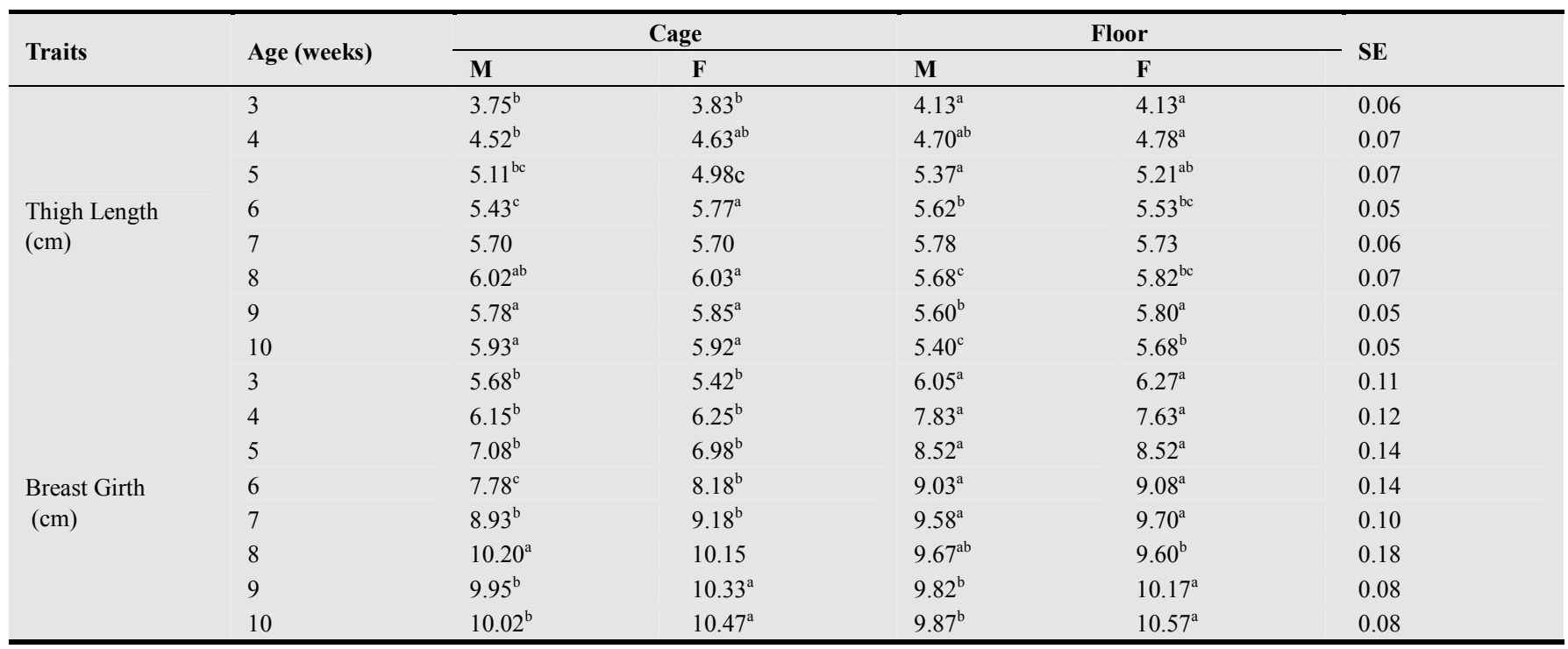

abc: means with different superscripts along rows are significantly different $(\mathrm{P}<0.01)$

\section{Acknowledgements}

The author appreciates the support and cooperation received from staff and management of Teaching and Research farm, Ekiti State University, Ado-Ekiti.

\section{References}

[1] FAO. "Guidelines for slaughtering, meat cutting and further processing". FAO Animal Production and Health paper No. 91. Rome, Italy. 170pp., 1991. 
[2] D. Gambo, O. M. Momoh, N. I. Dim and A. S Kosshak. "Body parameters and prediction of body weight from linear measurements in Coturnix quail". Liv. Res. for Rural Dev., 26(6), (2014).

[3] S. P. Muthukumar and A. K. DevRoy. "Alternate Poultry Production in India". An Overview. Copyright 2005-06 Sadana Publishers and Distributors. (2005). Retrieved from http://www.dairyyearbook.com/poultry

[4] K.A. Shahin and F.A. Elazeem. "Effects of breed and sex and diet and their interactions on carcass composition and tissue weight distribution of broiler chickens". Arch Tierzil 48, pp. 612-626, 2005.

[5] R. Tarhyel, B. K. Tanimomo and S. A. Hena. "Effect of sex, colour and weight group on carcass characteristics of Japanese quail”. Scientific J. Anim. Sci., 1(1), pp. 22-27, 2012.

[6] J. W. Merkeley, B. T. Weinland, G. W. Malone and G. W. Chaloupka. "Evaluation of five commercial broiler crosses. 2. Eviscerated yield and component parts". Poultry Sci., 59, pp.1755-1760, 1980.
[7] J. Wiseman and C. E. Lewise. "Influence of dietary energy and nutrient concentration on the growth of body weight and carcass components of broiler chickens". J. Agric. Sci., 131, pp.361-371, 1998.

[8] L. O. Ojedapo, T. A. Adedeji, A. O. Ige, T. B. Olayeni, S. A. Ameen and A. A. Ajagbe. "Evaluation of growth performance of three commercial layer strains in the Derived Savannah zone of Nigeria". Proceedings of $31^{\text {st }}$ Annual Conference, Nigeria Society for Animal Production. March $12^{\text {th }}-15^{\text {th }}$, 2006, Bayero University, Kano, Nigeria. pp. 259-261, 2006.

[9] J. Tarrago and F. Puchal. "Effect of strain, sex, and stocking rate on the performance and carcass yield of caged broilers". Br. Poult. Sci., 18, pp.95-99, 1977.

[10] F. O. Ajayi and O. Ejiofor. "Effects of genotype x sex interaction on growth and some development characteristics of Ross and Anak broiler strains in the high rainforest zone of Nigeria”. Asian J. Poult. Sci., pp 1-6, 2009.

[11] Statistical Analysis System SAS,. SAS Users Guide. Statistics, $8^{\text {th }}$ edition, SAS Institute Cary, NC, USA. 2001. 